\title{
Spatiotemporal expression pattern of alpha, beta, and gamma genes during BoHV-5 infection
}

\author{
Expressão temporal de genes alfa, beta e gama durante a \\ infecção pelo BoHV-5
}

\author{
Didier Quevedo Cagnini 1* (D); Peres Ramos Badial³; José Paes de Oliveira-Filho²; Alexandre Secorun Borges²; \\ João Pessoa de Araújo Jr. ${ }^{4}$ \\ ${ }^{1}$ Universidade Federal de Jataí, Ciências Biológicas, Campus Cidade Universitária, Jataí - GO, Brazil \\ ${ }^{2}$ Universidade Estadual Paulista "Júlio de Mesquita Filho", Faculdade de Medicina Veterinária, Departamento de Clínica Veterinária, \\ Laboratório de Biologia Molecular, Botucatu - SP, Brazil \\ ${ }^{3}$ Mississippi State University, College of Veterinary Medicine, Department of Pathobiology and Population Medicine, Mississippi State - USA \\ ${ }^{4}$ Universidade Estadual Paulista “Júlio de Mesquita Filho", Instituto de Biociências, Departamento de Microbiologia e Imunologia, \\ Laboratórios de Virologia Animal e Humana, Botucatu - SP, Brazil
}

\begin{abstract}
Bovine herpesvirus 5 is an alphaherpesvirus that causes nonsuppurative meningoencephalitis in cattle. This disease occurs naturally in either outbreaks or isolated cases, and exhibits low morbidity and high lethality. Although previous studies elucidated crucial aspects involved in the pathogenesis of the disease, there is a paucity of information regarding the molecular events contributing to infection and replication of BoHV-5. The objective of the present study was to determine the in vitro gene expression pattern of BoHV-5 (e.g., alpha, beta, and gamma genes) and host cells genes (GAPDH and $18 S$ ) over time utilizing different quantities of inoculated virus. Three BoHV-5 genes (bICP0, UL9, US4) and one structural bovine cell gene had their expression accessed by real-time PCR. While the expression of BoHV-5 genes increased during the course of infection, GAPDH gene expression decreased in the host cells, evidencing the effect of viral infection on the expression of bovine cell genes. The $18 \mathrm{~S}$ ribosomal RNA (rRNA) gene was constitutively expressed throughout BoHV-5 infection. Our data clearly demonstrates that GAPDH gene should not be used as a reference gene in studies of BoHV-5 infection because it was influenced by viral infection. However, $18 \mathrm{~S}$ rRNA was constitutively expressed and, therefore, is recommended for normalization of BoHV-5 infection studies in bovine cells. The expression of viral genes transcripts was not altered by increasing number of viral particles added to the culture. All viral genes included here demonstrated the same expression pattern over time and there was no difference in the expression of viral genes among the various time points. Our data show important differences comparing to classical studies regarding herpesvirus alpha, beta, and gamma genes expression. More research is necessary to improve our understanding about the BoHV-5 biology during infection. Studies employing next-generation sequencing (i.e., RNA-seq), using both in vitro and in vivo models, would be the next logical step to grasp the virus and host cell's transcriptome changes over the course of infection.
\end{abstract}

Keywords: Bovine herpesvirus 5. Quantitative PCR. Viral gene expression. Molecular biology.

\section{RESUMO}

Herpesvirus bovino 5 é um alfaherpesvírus causador de meningoencefalite não supurativa em bovinos. Esta doença possui ocorrência natural em surtos ou casos isolados, associadas a baixa morbidade e alta letalidade. Embora estudos anteriores tenham elucidado aspectos relacionados a patogenia da doença, há uma lacuna de conhecimento relacionado aos eventos moleculares que contribuem para a infecção e replicação do BoHV-5. O objetivo do presente estudo foi determinar a expressão gênica in vitro de genes virais (i.e., alfa, beta e gama) e das células hospedeiras (GAPDH e 18S) durante a infecção considerando diferentes momentos de infecção e quantidade de vírus utilizado. Três genes do BoHV-5 (bICP0, UL9, US4), um gene estrutural (GAPDH) e um gene constitutivo (18S) da célula bovina tiveram suas expressões avaliadas por PCR quantitativa (qPCR). Enquanto os genes virais tiveram sua expressão aumentada ao longo do tempo de infecção, o gene hospedeiro teve sua expressão diminuída, demonstrando a ação do vírus na expressão gênica de células bovinas in vitro. $\mathrm{O}$ gene constitutivo $18 \mathrm{~S}$ teve sua expressão mantida durante todos os momentos do experimento. Nossos resultados claramente demonstraram que o GAPDH não deve ser usado como gene de referência em estudos com infecção por BoHV-5 pois é influenciado pela infecção viral. Entretanto, o $18 \mathrm{~S}$ rRNA foi constitutivamente expresso e pode ser recomendado para normalização em células bovinas infectadas pelo vírus. A expressão de mRNA 
viral não foi alterada pela quantidade de vírus usada. Todos os genes virais demonstraram o mesmo padrão de expressão ao longo do tempo de infecção. Nossos resultados trazem importantes diferenças comparando aos estudos clássicos que avaliaram a expressão de genes alfa, beta e gama. Mais estudos são necessários para aumentar o conhecimento da biologia molecular do BoHV-5. Estudo utilizando sequenciamento de última geração (i.e., RNA-seq), usando modelos in vitro e in vivo, aparentam ser o próximo passo lógico para acessar as alterações do transcriptoma do hospedeiro e viral ao longo do curso da infecção.

Palavras-chave: Herpesvirus bovino 5. PCR quantitativa. Expressão gênica viral. Biologia molecular.

\section{Correspondence to:}

Didier Quevedo Cagnini

Universidade Federal de Jataí, Ciências Biológicas, Campus

Cidade Universitária

BR 364, km 195, nº 3800

CEP: 75801-615, Jataí - GO, Brazil

e-mail: didiercagnini@gmail.com

Submited: October 09, 2018

Approved: February 02, 2019

How to cite: Cagnini DQ, Badial PR, Oliveira Filho JP, Borges AS, Araújo Jr. JP. Spatiotemporal expression pattern of alpha, beta, and gamma genes during BoHV-5 infection. Braz J Vet Res Anim Sci. 2019;56(1):e150972. https://doi. org/10.11606/issn.1678-4456.bjvras.2019.150972.

\section{Introduction}

Bovine herpesvirus $5^{1}$ is an alphaherpesvirus (Davison et al., 2009; Del Médico Zajac et al., 2010; Franco \& Roehe, 2007) that causes nonsuppurative meningoencephalitis, mainly in young cattle. This disease naturally occurs in either outbreaks or isolated cases, and exhibits low morbidity and high lethality (Rissi et al., 2006; Salvador et al., 1998). BoHV-5 infection, besides leading to cattle death, is an important differential diagnosis of other neurological diseases (e.g., rabies and bovine spongiform encephalopathy). The herpesvirus genome comprises three classes of genes known as immediate early (IE) or alpha ( $\alpha$ ), early (E) or beta $(\beta)$, and late $(\mathrm{L})$ or gamma $(\gamma)$ (Honess \& Roizman, 1974). In permissive cells, the process of Human herpesvirus 1 (HHV-1) viral replication takes 18 to $20 \mathrm{~h}$ (Pellett \& Roizman, 2007). Orchestrated gene and protein expressions are crucial for viral replication after infection in epithelial cells of the nasal or vaginal mucosa (Bagust, 1972; Bagust \& Clark, 1972; Padgett et al., 2007; Van Lint \& Knipe, 2009).

The classical herpesvirus cascade of alpha, beta, and gamma gene expression was first studied in vitro using the protein expression profile of HHV-1, formerly named herpes simplex virus 1 (HSV-1) (Honess \& Roizman, 1974). The expression peak of a genes occurs within 2 to $4 \mathrm{~h}$

${ }^{1}$ BoHV-5 post-infection (p.i.), encoding proteins that regulate the expression of subsequent viral genes (Honess \& Roizman, 1974) and contribute to evasion of the cellular responses to the infection (Van Lint \& Knipe, 2009). Although the expression of $\beta$ genes peaks at 5 to $7 \mathrm{~h}$ p.i., it ranges from 3 to 15 h p.i. (Honess \& Roizman, 1974). In addition, expression of $\beta$ genes induce viral DNA replication within the cell, and also downregulates a genes (Van Lint \& Knipe, 2009). The expression of $\gamma$ genes peaks at $6 \mathrm{~h}$ p.i. encoding viral structural proteins. However, those viral genes can be detected at low levels at $3 \mathrm{~h}$ p.i. and reach maximum expression at $12 \mathrm{~h}$ p.i. (Nichol et al., 1996). DNA viral replication stimulates expression of $\gamma$ genes at high levels, whereas it shuts off expression of a genes (Weir, 2001).

Herpesvirus genetic complexity, evolutionary diversity, and widely differing biological properties have generated a considerable research effort worldwide (Van Lint \& Knipe, 2009). Nevertheless, the current understanding of the biology underlying the complex life cycle of herpes simplex virus (HSV) is still incomplete (Sawtell et al., 2006).

The ICPO is a very important $\alpha$ gene that can stimulate the transcription of others $\alpha, \beta$, and $\gamma$ genes (Engels \& Ackermann, 1996). It has also been implicated in the establishment and reactivation of the virus from latency (Du et al., 2011; Roizman, 2011; Sandri-Goldin, 2003). Thus, induction of the expression of ICP0 gene or its homologs, as bICP0 in BoHV-5, may be sufficient to initiate reactivation of latent herpesviruses (Engels \& Ackermann, 1996).

The UL9 gene is a $\beta$ gene that encodes an origin-binding protein (Olivo et al., 1988). This protein is one of the seven proteins that are essential for the replication of HHV-1 DNA (Boehmer \& Lehman, 1997). The UL9 protein functions to initiate HSV-1 DNA replication by binding and unwinding the three origins of HSV-1 DNA replication, and by recruiting the replication machinery to these origins (Lee \& Lehman, 1997; Lehman \& Boehmer, 1999).

The US4 is a $\gamma$ gene that is responsible for the transcription of the glycoprotein G (gG) (Engelhardt \& Keil, 1996). The BoHV-1 homologous gG is involved in cell-to-cell dissemination (Nakamichi et al., 2000), stabilizing the cell structure, postponing apoptotic process (Nakamichi et al., 2001), and facilitating viral cell-to-cell spread by maintaining 
the cell-to-cell junctions among the infected cells (Nakamichi et al., 2002). Furthermore, this gG can interfere at different distinct stages of chemokine action and therefore constitutes yet another mechanism of alphaherpesviruses to evade the immune system (Van De Walle et al., 2008). The BoHV-1 gG has the potential to interfere with acute inflammatory responses mediated by polymorphonuclear leukocytes (Liu et al., 2013). The BoHV-5 gG function as broad-spectrum chemokine binding proteins (Bryant et al., 2003).

The understanding of the spatiotemporal expression patterns of BoHV- 5 during viral replication remains poorly explored. The study of the expression of herpesviruses genes contributes to the identification of potential viral target molecules that could be pharmacologically exploited to eliminate viral replication. Such studies could also assist in the better understanding of transcriptional profile changes in host cells after viral infection, identification of altered molecular functions and biological processes, and the role of herpesvirus in inducing host cell latency. In the present study, we used real-time PCR to characterize the in vitro spatiotemporal expression profile of essential BoHV-5 and host cell's genes.

\section{Materials and Methods}

Madin-Darby Bovine Kidney (MDBK) cells were inoculated with SV-507/99 strain of BoHV-5 (Delhon et al., 2003) to evaluate the spatiotemporal mRNA expression profile of three BoHV-5 genes (bICPO, UL9, and US4) and two cellular genes (GAPDH and 18S) using real-time PCR. MDBK cells were maintained with Dulbecco's modified Eagle medium (DMEM) supplemented with non-essential amino acids $\left(\mathrm{Gibco}^{\circledR}\right.$ ) and 10\% fetal bovine serum (FBS) in a humidified $5 \% \mathrm{CO}_{2}$ atmosphere at $37^{\circ} \mathrm{C}$. Experiments were performed in triplicate.

MDBK cells were seeded into culture flasks $\left(25 \mathrm{~cm}^{2}\right) 24 \mathrm{~h}$ prior to use, and infected at $80-90 \%$ confluence. The MDBK monolayers were infected at multiplicity of infection ${ }^{2}$ of 0.75-1 or 7.5-10. The inoculum was maintained into the culture for 1 hour to properly adsorb to the cells, and then removed and washed with fresh DMEM. This time point was considered moment $0 \mathrm{~h}$ p.i. Monolayers were harvested at $0 \mathrm{~h}, 6 \mathrm{~h}, 12 \mathrm{~h}$, or $24 \mathrm{~h}$ p.i. Also, mock-infected MDBK controls were obtained at the same time points. Total RNA was purified using Total RNA Purification Kit (Norgen Biotek Corp.). RNA was frozen to $-80^{\circ} \mathrm{C}$ until cDNA synthesis. Cell counting was compared between $0 \mathrm{~h}$ and $24 \mathrm{~h}$ p.i to evaluate possible dissimilarities in the number of harvested cells along the experiments.

RNA purity and concentration were accessed using a NanoDrop ${ }^{\mathrm{Tm}}$ spectrophotometer (Nanodrop 1000 Spectrophotometer, Thermo Scientific $\left.{ }^{\mathrm{Tm}}\right)$. Further quality analysis was carried out using Bioanalyzer (RNA 6000 NanoLabChip kit/ 2100 Agilent Technologies). Total RNA was treated with RQ1 RNAse-Free DNase (Promega) to eliminate genomic DNA contamination. After that, samples were submitted to PCR according to Cagnini et al. (2015) and to real-time PCR using the primers presented in Table 1 to ensure the absence of DNA. Then, $900 \mathrm{ng}$ of the RNA samples was primed with random hexamers and used to synthesize first-strand cDNA using the ImProm-II ${ }^{\mathrm{mm}}$ Reverse Transcription System (Promega).

Primers were designed using the Primer Express 3.0 software (Applied Biosystems) (Table 1) and directed against partial sequences of viral (bICP0, UL9 and US4) and cellular genes (GAPDH and 18S) of the BoHV-5 (AY261359.1) and bovine genomes (GCA_000003055.4), respectively. We used the GAPDH gene to evaluate the effect of viral infection in the expression of a structural host cell gene, and $18 S$ as a reference gene.

Relative mRNA expression was quantified using a 7500 Fast Real-Time PCR System (Applied Biosystem $\mathrm{s}^{\mathrm{Tx}}$ ), and analyzed using the comparative Ct method $\left(2^{-\Delta \Delta \mathrm{Ct}}\right.$ method) (Livak \& Schmittgen, 2001). Briefly, each $20 \mu \mathrm{L}$ qPCR reaction was carried out in triplicate, containing $0.3 \mu \mathrm{M}$ of each primer, $2 \mu \mathrm{L}$ of cDNA template, $10 \mu \mathrm{L}$ of $\mathrm{GoTaq}^{\circledR}{ }^{\circledR P C R}$ Master Mix (Promega), and $6.8 \mu \mathrm{L}$ of nuclease-free water. The following qPCR amplification conditions were $95^{\circ} \mathrm{C}$ for $2 \mathrm{~min}, 40$ cycles at $95^{\circ} \mathrm{C}$ for $15 \mathrm{sec}$ and $60^{\circ} \mathrm{C}$ for $1 \mathrm{~min}$, followed by a melting curve. Also, negative controls were included in triplicate in each plate. Five-fold standard curves were used to test primers' efficiency. Data analysis was performed by normalizing

Table 1 - Primers used to evaluate BoHV-5 and MDBK cells gene expression*

\begin{tabular}{llc}
\hline \multicolumn{1}{c}{ Primer } & \multicolumn{1}{c}{ Sequence $\left(\mathbf{5}^{\prime}\right.$ - $\mathbf{3}^{\prime} \mathbf{)}$} & $\begin{array}{c}\text { Product } \\
\text { size (bp) }\end{array}$ \\
\hline bICP0 F & CACACCACCGCGTATTTGC & 85 \\
bICP0 R & TTACTTTTGGTTTGGGGATGACA & \\
US4 F & AGCGGGACCTACGTCTACTT & 91 \\
US4 R & ATTTGTGGATGTCGGCACCT & \\
UL9 F & GCTGGTGCAGGTGGAAA & 116 \\
UL9 R & CCATCGTCGGCGAATACAA & \\
GAPDH Bos taurus F & TGACCCCTTCATTGACCTTC & 120 \\
GAPDH Bos taurus R & ATGGCCTTTCCATTGATGAC & \\
18S bos taurus F & GAGAAACGGCTACCACATCCA & 170 \\
18S bos taurus R & CACCAGACTTGCCCTCCAAT & \\
\hline * F = forward; R = reverse; R 2 $>0.99 ;$ Efficiency varied from 92\% to $95 \%$
\end{tabular}


amplification values of the target genes with the endogenous control. We included one sample (6 h p.i.) to serve as calibrator sample to certify that efficiency was the same among real-time PCR plaques.

Data were analyzed in a completely randomized design with repeated measures. Relative gene expression data was transformed to the $\log _{10}$ scale to achieve normality. The data is presented as the geometric mean with $95 \%$ confidence intervals. A linear mixed model (PROC MIXED; SAS 9.4; SAS Institute Inc., Cary, NC, USA) was used to compare the mean expression values among time points, genes, and their interactions. A first-order autoregressive covariance structure resulted in the best fit based on the Bayesian information criterion and was used to model the correlation among the expression values of each gene in each MOI level. The Tukey test was used to adjust the $p$ values resulting of the multiple comparisons. Analyses were conducted using a level of significance of $\mathrm{P}=0.05$.

\section{Results and discussion}

The Relative mRNA expression of viral (bICP0, UL9, and US4) and cellular (GAPDH) genes during the course of BoHV-5 (strain SV507/99) infection in MDBK cells is presented in Figure 1. Mock-infected cells exhibited stable GAPDH mRNA expression throughout the study. However, GAPDH mRNA expression in the BoHV-5 infected cells decreased continuously from $12 \mathrm{~h}$ to $24 \mathrm{~h}$ p.i. $(\mathrm{p}<0.001)$ compared to $0 \mathrm{~h}$ and $6 \mathrm{~h}$ p.i. On the other

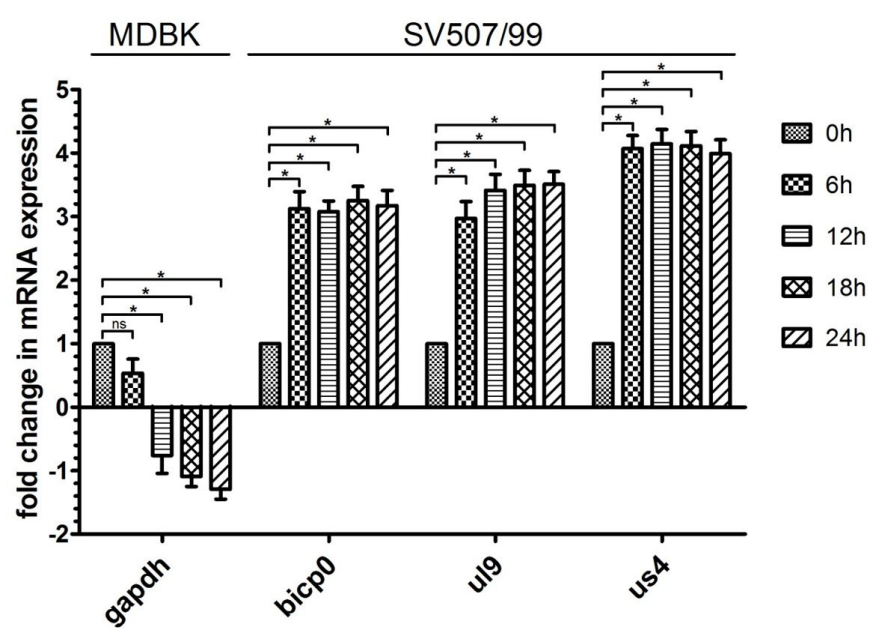

Figure 1 - Relative mRNA expression of viral (bICP0, UL9, and US4) and cellular (GAPDH) genes during $24 \mathrm{~h}$ of the BoHV-5 (strain SV507/99) infection in MDBK cells. The 18S gene was used as a reference gene to calculate the relative mRNA expression. The mean relative expression values with standard deviation are shown. Asterisks indicate significant $(\mathrm{P}<0.001)$ differences between indicated sampling times hand, $18 S$ rRNA maintained constant expression levels during the $24 \mathrm{~h}$ period of BoHV-5 infection. Similar results were observed in human embryonic lung fibroblasts infected with HHV-1 where the expression of host cell's proteins such as GAPDH and $\beta$-actin genes decreased by several orders of magnitude during HSV-1 infection, but $18 S$ rRNA was constitutively expressed (Nystrom et al., 2004). Another study demonstrated that GAPDH mRNA levels were drastically reduced during infection with HHV-1 infection of HeLa and HEL cells due to virion host shutoff (VHS) protein expression, product of the UL41 gene (Hsu et al., 2005). The viral VHS protein is an mRNA-specific RNase linked to the shutoff of host gene expression early in infection and presents a highly selective activity by targeting stable host mRNAs and $\alpha$ mRNAs, while sparing other viral mRNAs (Shu et al., 2013; Van Lint \& Knipe, 2009; Weir, 2001). Previous studies have demonstrated that the translation of mRNA encoding ribosomal proteins (e.g., 18s) persists and is even favored over other mRNAs during HHV-1 infection (Greco et al., 1997; Simonin et al., 1997) by a mechanism that redirects the polyribosome complex to mRNAs of ribosomal proteins (Greco et al., 1997). It is very likely that the BoHV-5 infection induced downregulation of GAPDH mRNA, while not interfering with 18s mRNA expression, using a similar mechanism.

Therefore, 18S rRNA is a reliable constitutive gene for monitoring viral and cellular gene expression in BoHV-5-infected cells, while GAPDH gene should not be used for this purpose. However, $18 S$ rRNA was the least reliable reference gene in a list of 10 commonly used reference genes that were studied in a variety of cell types infected with Human immunodeficiency virus 1 (HIV-1), HHV-1, Varicela-Zoster virus and Cytomegalovirus (Watson et al., 2007). These findings highlight the importance of evaluating the reference gene before using it in an experiment.

When individually compared, all viral genes demonstrated the same expression pattern and there was no difference of viral genes expression among the time course of infection. Viral genes were highly expressed in all moments when compared to the moment $0 \mathrm{~h}$ p.i $(\mathrm{p}<0.01)$. According to classical herpesvirus protein expression data (Honess \& Roizman, 1974), ICP0 (bICP0 homologous), UL9, and US4 proteins can be detected at $6 \mathrm{~h}$ p.i., which corroborates with the mRNA expression data in this study.

bICP0 transcripts were upregulated from $6 \mathrm{~h}$ to $24 \mathrm{~h}$ p.i. $(\mathrm{P}<0.001)$ compared with $0 \mathrm{~h}$ p.i. However, the $\alpha$ proteins 
should decrease at $12 \mathrm{~h}$ p.i (Honess \& Roizman, 1974). The expression of ICPO gene in HSV-1, which is orthologous to IICP0 in cattle, peaks at $3 \mathrm{~h}$ p.i. and decreases after $7 \mathrm{~h}$ p.i (Nichol et al., 1996; Režuchová et al., 2003). However, BoHV-1 infection induces constitutive mRNA expression of IICP0 gene because it contains immediate early and early promoters (Fraefel et al., 1994). Therefore, BoHV-5 may induce a similar $6 I C P 0$ gene expression pattern than BoHV-1, suggesting a similar viral behavior/biology during infection/replication/pathogenesis. BHV-5 is very similar to BHV-1, since they have high level of amino acid identity in their protein repertoires (average, 82\%) (Delhon et al., 2003), which should explain their similar bICPO gene expression pattern.

UL9 mRNA expression in the BoHV-5 infected cells increased from $6 \mathrm{~h}$ to $24 \mathrm{~h}$ p.i. $(\mathrm{p}<0.001)$ compared with $0 \mathrm{~h}$ p.i. Previous studies have demonstrated that UL9 gene expression in HHV-1 infection begins at 1.5 h p.i. and increases abundantly from 3 to $12 \mathrm{~h}$ p.i., peaking at $8 \mathrm{~h}$ p.i. (Durmanova et al., 2001; Režuchová et al., 2003). UL9 gene was differentially expressed 8 to $12 \mathrm{~h}$ p.i. compared to $1 \mathrm{~h}$ p.i. in cultured cells infected with pseudorabies virus (Flori et al., 2008). In the present study, we observed high expression level of UL9 transcripts $6 \mathrm{~h}$ p.i., which increased at $12 \mathrm{~h}$ p.i. and remained high thereafter. The moment $24 \mathrm{~h}$ p.i. was not compared to previous studies because those studies did not have that time point (Durmanova et al., 2001; Režuchová et al., 2003).

US4 mRNA transcripts were upregulated from 6 to $24 \mathrm{~h}$ p.i. ( $\mathrm{p}<0.001)$ compared with 0 h p.i. Expression of late viral genes at $1 \mathrm{~h}$ pi. (UL49.5 gene) and 8 to $12 \mathrm{~h} \mathrm{p.i} \mathrm{(UL36} \mathrm{and}$ UL41 genes) were described in the microarray of pseudorabies virus infection in cultured cells (Flori et al., 2008). The UL22 gene, a late gene that encodes glycoprotein $\mathrm{H}$, was expressed just 2 hours after the infection of MDBK cells by BoHV- 5 (Meyer et al., 1999). The UL27 gene (Rafield \& Knipe, 1984), and ICP5, US6, and ICP34.5 genes (Van Lint \& Knipe, 2009), all late genes, were also expressed early in infection.

Finally, we consider that a next step in our attempt to understand BoHV-5 molecular biology could be to study the expression of the $6 I C P 0, U L 9, U S 4$, and GAPDH at $1 \mathrm{~h}, 2 \mathrm{~h}$, $3 \mathrm{~h}, 4 \mathrm{~h}, 5 \mathrm{~h}$ and $6 \mathrm{~h}$ p.i. to determine exactly the moment at which viral and host cell genes start to be differentially expressed. Moreover, in a second moment RNA-Seq, it would also be very informative, mainly regarding to host differential expressed genes and the molecular and cellular processes modified by viral replication. In a third moment, we would expand our approach and perform the above studies using animal models to better understand the molecular biology interaction between BoHV-5 and host cells in a more complex system.

\section{Conclusion}

BoHV-5 alpha ( $b I C P 0)$, beta (UL9), and gamma (US4) genes presented a similar expression pattern (upregulated) and the cellular gene (GAPDH) was markedly downregulated by viral replication during the time course of infection. The $6 I C P 0$ gene was constitutively expressed as previously described in BoHV-1 infection. This viral gene could be used in future in vitro studies as a reference gene to the virus, but more studies are needed to prove this claim. The $18 S$ was a good reference gene for our study, while the GAPDH was clearly not. The differences observed in the present study between the expression pattern of key BoHV-5 and HHV-1 published gene expression data might be related to the viral species differences (e.g., tropism, target cell, genetic material, or genomic structure), distinct molecular mechanisms involved in the pathogenesis to infect the host species, or because different techniques were used to compare gene expression in those studies. We consider that more research using modern techniques such as quantitative PCR, microarrays, and RNA-Seq are necessary to expand the current knowledge about BoHV-5 molecular biology to better understand how the replication of this virus affects host cells and how virus and host cells communicate with each other.

\section{Conflict of interest}

The author(s) declared no potential conflicts of interest with respect to the research, authorship, and/or publication of this article

\section{Ethics Statement}

This material has not been published in whole or in part elsewhere. All authors have been personally and actively involved in substantive word leading to the manuscript. This research project was submitted and approved by Research Ethics Committee of FMVZ-Unesp, Botucatu, protocol number 146/2011-CEUA.

\section{Acknowledgements}

We would like to thank the Virology Laboratory of the Federal University of Santa Maria, Santa Maria, RS, Brazil, for providing the BoHV-5 SV507/99 strain. The present research was supported by FAPESP 14/13532-3. 


\section{References}

Bagust TJ. Comparison of the biological, biophysical and antigenic properties of four strains of infectious bovine rhinotracheitis herpesvirus. J Comp Pathol. 1972;82(4):36574. http://dx.doi.org/10.1016/0021-9975(72)90035-7. PMid:4346155.

Bagust TJ, Clark L. Pathogenesis of meningo-encephalitis produced in calves by infectious bovine rhinotracheitis herpesvirus. J Comp Pathol. 1972;82(4):375-83. http:// dx.doi.org/10.1016/0021-9975(72)90036-9. PMid:4346156.

Boehmer PE, Lehman IR. Herpes Simplex Virus DNA Replication. Ann Rev Biochem. 1997;66(1):347-84. http:// dx.doi.org/10.1146/annurev.biochem.66.1.347

Bryant NA, Davis-Poynter N, Vanderplasschen A, Alcami A. Glycoprotein $\mathrm{G}$ isoforms from some alphaherpesviruses function as broad-spectrum chemokine binding proteins. EMBO J. 2003;22(4):833-46. http://dx.doi.org/10.1093/ emboj/cdg092. PMid:12574120.

Cagnini DQ, Cunha PHJ, Pantoja JCF, Badial PR, Oliveira-Filho JP, Araújo-Junior JP, Alfieri AA, Borges AS. Histopathological, immunohistochemical, and molecular study of BHV-5 infection in the central nervous system of experimentally infected calves. Pesqui Vet Bras 2015;35(4):337-43. http:// dx.doi.org/10.1590/S0100-736X2015000400004

Davison AJ, Eberle R, Ehlers B, Hayward GS, McGeoch DJ, Minson AC, Pellett PE, Roizman B, Studdert MJ, Thiry E. The order Herpesvirales. Arch Virol. 2009;154(1):171-7. http:// dx.doi.org/10.1007/s00705-008-0278-4. PMid:19066710.

Del Médico Zajac MP, Ladelfa MF, Kotsias F, Muylkens B, Thiry J, Thiry E, Romera SA. Biology of bovine herpesvirus 5. Vet J. 2010;184(2):138-45.

Delhon G, Moraes MP, Lu Z, Afonso CL, Flores EF, Weiblen R, Kutish GF, Rock DL. Genome of bovine herpesvirus 5. J Virol. 2003;77(19):10339-47.

Du T, Zhou G, Roizman B. HSV-1 gene expression from reactivated ganglia is disordered and concurrent with suppression of latency-associated transcript and miRNAs. Proc Natl Acad Sci USA. 2011;108(46):18820-4. http:// dx.doi.org/10.1073/pnas.1117203108. PMid:22065742.
Durmanová V, Rezuchová I, Kosovský J, Kúdelová M, Rajcáni J. The UL9 ori-binding protein of herpes simplex virus 1: its expression and localization in vero cells. Acta Virol. 2001;45(5-6):311-7. PMid:12083331.

Engelhardt T, Keil GM. Identification and characterization of the bovine Herpesvirus 5 US4 gene and gene products. Virology. 1996;225(1):126-35. http://dx.doi.org/10.1006/ viro.1996.0580. PMid:8918539.

Engels M, Ackermann M. Pathogenesis of ruminant herpesvirus infections. Vet Microbiol. 1996;53(1-2):3-15.

Flori L, Rogel-Gaillard C, Cochet M, Lemonnier G, Hugot K, Chardon P, Robin S, Lefèvre F. Transcriptomic analysis of the dialogue between Pseudorabies virus and porcine epithelial cells during infection. BMC Genomics, 2008;9(1):123. https://doi.org/10.1186/1471-2164-9-123.

Fraefel C, Zeng J, Choffat Y, Engels M, Schwyzer M, Ackermann M. Identification and zinc dependence of the bovine herpesvirus 1 transactivator protein BICP0. JVirol. 1994;68(5):3154-62.

Franco AC, Roehe PM. Herpesviridae. In: Flores EF, editor. Virologia Veterinária. Santa Maria: UFSM; 2007. p. 435-88.

Greco A, Laurent AM, Madjar JJ. Repression of beta-actin synthesis and persistence of ribosomal protein synthesis after infection of HeLa cells by herpes simplex virus type 1 infection are under translational control. Mol Gen Genet. 1997;256(3):320-7. http://dx.doi.org/10.1007/s004380050575. PMid:9393457.

Honess RW, Roizman B. Regulation of herpesvirus macromolecular synthesis I. Cascade regulation of the synthesis of three groups of viral proteins. J Virol. 1974;14(1):8-19.

Hsu W-L, Saffran HA, Smiley JR. Herpes simplex virus infection stabilizes cellular IEX-1 mRNA. J Virol. 2005;79(7):4090-98.

Lee SSK, Lehman IR. Unwinding of the Box I element of a herpes simplex virus Type 1 origin by a complex of the viral origin binding protein, single-strand DNA binding protein, and single-stranded DNA. Proc Natl Acad USA, 1997;94(7):2838-42. 
Lehman IR, Boehmer PE. Replication of herpes simplex virus DNA. J Biol Chem. 1999;274(40):28059-62. https:// doi.org/10.1074/jbc.274.40.28059

Liu Z, Bethunaickan R, Sahu R, Brenner M, Laragione T, Gulko PS, Davidson A. The multiple chemokine-binding Bovine Herpesvirus 1 Glycoprotein G (BHV1gG) inhibits polymorphonuclear cell but not monocyte migration into inflammatory sites. Mol Med. 2013;19(1):27685. http://dx.doi.org/10.2119/molmed.2012.00339. PMid:23979709.

Livak KJ, Schmittgen TD. Analysis of relative gene expression data using real-time quantitative PCR and the $2-\Delta \Delta \mathrm{CT}$ Method. Methods. 2001;25(4):402-8

Meyer G, Bare O, Thiry E. Identification and characterization of bovine herpesvirus type 5 glycoprotein $\mathrm{H}$ gene and gene products. J Gen Virol 1999;80(11):2849-59.

Nakamichi K, Kuroki D, Matsumoto Y, Otsuka H. Bovine herpesvirus 1 glycoprotein $\mathrm{G}$ is required for prevention of apoptosis and efficient viral growth in rabbit kidney cells. Virology. 2001;279(2):488-98. http://dx.doi.org/10.1006/ viro.2000.0740. PMid:11162805.

Nakamichi K, Matsumoto Y, Otsuka H. Bovine herpesvirus 1 glycoprotein $\mathrm{G}$ is necessary for maintaining cell-to-cell junctional adherence among infected cells. Virology. 2002;294(1):22-30.

Nakamichi K, Ohara K, Kuroki D, Otsuka H. Bovine herpesvirus 1 glycoprotein $\mathrm{G}$ is required for viral growth by cell-to-cell infection. Virus Res. 2000;68(2):175-81. http://dx.doi.org/10.1016/S0168-1702(00)00171-4. PMid:10958989.

Nichol PF, Chang JY, Johnson EM Jr, Olivo PD. Herpes simplex virus gene expression in neurons: viral DNA synthesis is a critical regulatory event in the branch point between the lytic and latent pathways. J Virol. 1996;70(8):5476-86. PMid:8764059.

Nyström K, Biller M, Grahn A, Lindh M, Larson G, Olofsson $S$. Real time PCR for monitoring regulation of host gene expression in herpes simplex virus type 1-infected human diploid cells. J Virol Methods. 2004;118(2):83-94. http:// dx.doi.org/10.1016/j.jviromet.2004.01.019. PMid:15081603.

Olivo PD, Nelson NJ, Challberg MD. Herpes simplex virus DNA replication: the UL9 gene encodes an origin-binding protein. Proc Natl Acad. USA, 1988;85(15):5414-18. https:// doi.org/10.1073/pnas.85.15.5414.
Padgett DA, Bailey MT, Sheridan JF. Herpesviruses. In: Schaechter M. editor. Encyclopedia of stress. 2nd ed. New York: Academic Press; 2007. p. 305-311.

Pellett PE, Roizman B. The family Herpesviridae: a brief introduction. In: Knipe DM, Howley PM, editors. Fields virology. 5th ed. Philadelphia: Wolters Kluwer/Lippincott Williams and Wilkins; 2007. p. 2479-2500.

Rafield LF, Knipe DM. Characterization of the major $m R N A s$ transcribed from the genes for glycoprotein $B$ and DNA-binding protein ICP8 of herpes simplex virus type 1. J Virol. 1984;49(3):960-69.

Režuchová I, Kúdelová M, Durmanová V, Vojvodová A, Košovský J, Rajčáni J. Transcription at early stages of herpes simplex virus 1 infection and during reactivation. Intervirology, 2003;46(1):25-34. https://doi.org/10.1159/000068121. PMID: 12566696.

Rissi DR, Oliveira FN, Rech RR, Pierezan F, Lemos RAA, Barros CSL. Epidemiologia, sinais clínicos e distribuição das lesões encefálicas em bovinos afetados por meningoencefalite por herpesvírus bovino-5. Pesq Vet Bras. 2006;26(2):123132. http://dx.doi.org/10.1590/S0100-736X2006000200010.

Roizman B. The checkpoints of viral gene expression in productive and latent infection: the role of the HDAC/CoREST/ LSD1/REST repressor complex. J Virol. 2011;85(15):747482. https://doi.org/10.1128/jvi.00180-11.

Salvador SC, Lemos RAA, Riet-Correa F, Roehe PM, Osório ALAR. Meningoencefalite em bovinos causada por herpesvírus bovino-5 no Mato Grosso do Sul e São Paulo. Pesq Vet Bras. 1998;18(2):76-83. http://dx.doi.org/10.1590/ S0100-736X1998000200007.

Sandri-Goldin RM. Replication of the herpes simplex virus genome: does it really go around in circles? Proc Natl Acad Sci USA. 2003;100(13):7428-9. http://dx.doi.org/10.1073/ pnas.1432875100. PMid:12810944.

Sawtell NM, Thompson RL, Haas RL. Herpes simplex virus DNA synthesis is not a decisive regulatory event in the initiation of lytic viral protein expression in neurons in vivo during primary infection or reactivation from latency. J Virol. 2006;80(1):38-50. http://dx.doi.org/10.1128/ JVI.80.1.38-50.2006. PMid:16352529.

Shu M, Taddeo B, Zhang W, Roizman B. Selective degradation of mRNAs by the HSV host shutoff RNase is regulated by the UL47 tegument protein. Proc Natl Acad 
Sci USA. 2013;110(18):E1669-75. https://doi.org/10.1073/ pnas. 1305475110 .

Simonin D, Diaz JJ, Massé T, Madjar JJ. Persistence of ribosomal protein synthesis after infection of HeLa cells by herpes simplex virus type 1. J Gen Virol. 1997;78(Pt 2):435-43. http://dx.doi.org/10.1099/0022-1317-78-2-435. PMid:9018067.

Van De Walle GR, Jarosinski KW, Osterrieder N. Alphaherpesviruses and chemokines: pas de deux not yet brought to perfection. J Virol. 2008;82(13):6090-97. https:// doi.org/10.1128/jvi.00098-08.

Van Lint AL, Knipe DM. Herpesviruses. In: Schaechter M, editor. Encyclopedia of microbiology. 3rd ed. Oxford:
Academic Press; 2009. p. 376-390. http://dx.doi.org/10.1016/ B978-012373944-5.00305-9.

Watson S, Mercier S, Bye C, Wilkinson J, Cunningham AL, Harman AN. Determination of suitable housekeeping genes for normalisation of quantitative real time PCR analysis of cells infected with human immunodeficiency virus and herpes viruses. Virol J. 2007;4(130):1-5. https:// doi.org/10.1186/1743-422x-4-130. PMid:18053162.

Weir JP. Regulation of herpes simplex virus gene expression. Gene. 2001;271(2):117-30. http://dx.doi.org/10.1016/S03781119(01)00512-1. PMid:11418233.

Authors Contributions: All authors read and approved the final manuscript. 